\title{
THE RELATION OF STRENGTH OF STIMULUS TO RAPIDITY OF HABIT-FORMATION \\ $\mathbf{B Y}$
}

ROBERT M. YERKES AND JOHN D. DODSON.

(From the Harvard Psychological Laboratory)

With Five Figures.

In connection with a study of various aspects of the modifiability of behavior in the dancing mouse a need for definite knowledge concerning the relation of strength of stimulus to rate of learning arose. It was for the purpose of obtaining this knowledge that we planned and executed the experiments which are now to be described. Our work was greatly facilitated by the advice and assistance of Doctor E. G. Martin, Professor G. W. Pierce, and Professor A. E. KenNELlY, and we desire to express here both our indebtedness and our thanks for their generous services.

The habit whose formation we attempted to study quantitatively, with respect to the strength of the stimulus which favored its formation, may be described as the white-black discrimination habit. Of the mice which served as subjects in the investigation it was demanded that they choose and enter one of two boxes or passage-ways. One of the boxes was white; the other black. No matter what their relative positions, the subject was required to choose the white one. Attempts to enter the black box resulted in the receipt of a disagreeable electric shock. It was our task to discover (I) whether the strength of this electric stimulus influences the rapidity with which dancers acquire the habit of avoiding the black passage-way, and if so, (2) what particular strength of stimulus is most favorable to the acquisition of this habit.

As a detailed account of the important features of the whiteblack visual discrimination habit in the dancer has already been published, ${ }^{1}$ a brief description of our method of experimentation

1 Yerres, Rorzrt M. The dancing mouse. New York: The Macmillan Company. See especially p. $9^{2}$, et seq. 1908 . 
460 Fournal of Comparative Neurology and Psychology.

will suffice for the purposes of this paper. A sketch of the experiment box used by us in this investigation appears as fig. I, and a ground plan of the box with its electric attachments, as fig. 2 .

This apparatus consisted of a wooden box $94 \mathrm{~cm}$. long; $30 \mathrm{~cm}$. wide; and II. $5 \mathrm{~cm}$. deep (inside measurements), which was divided

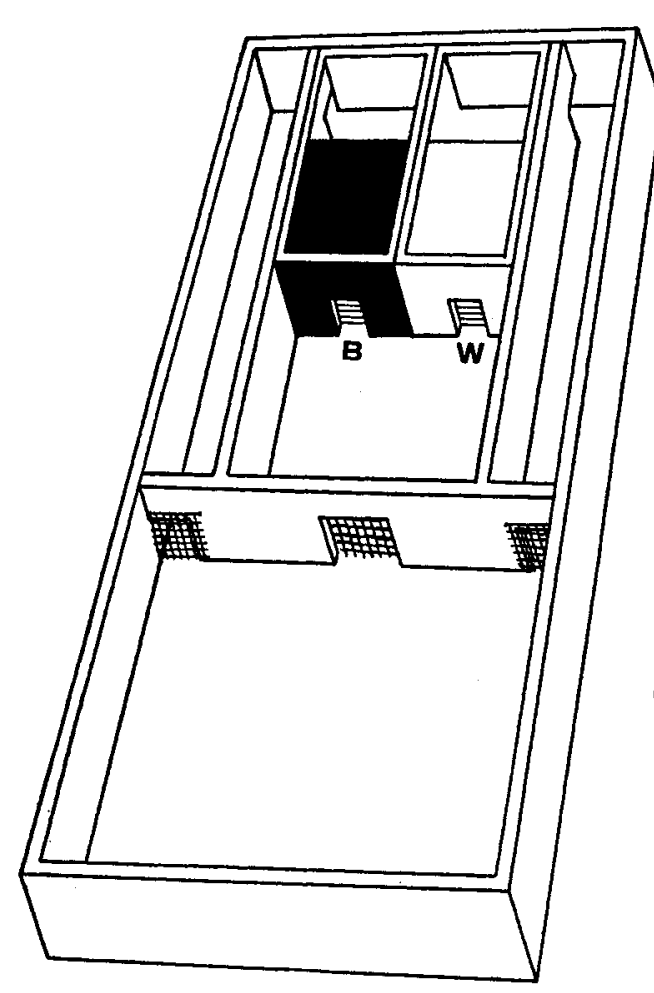

FIG. I.

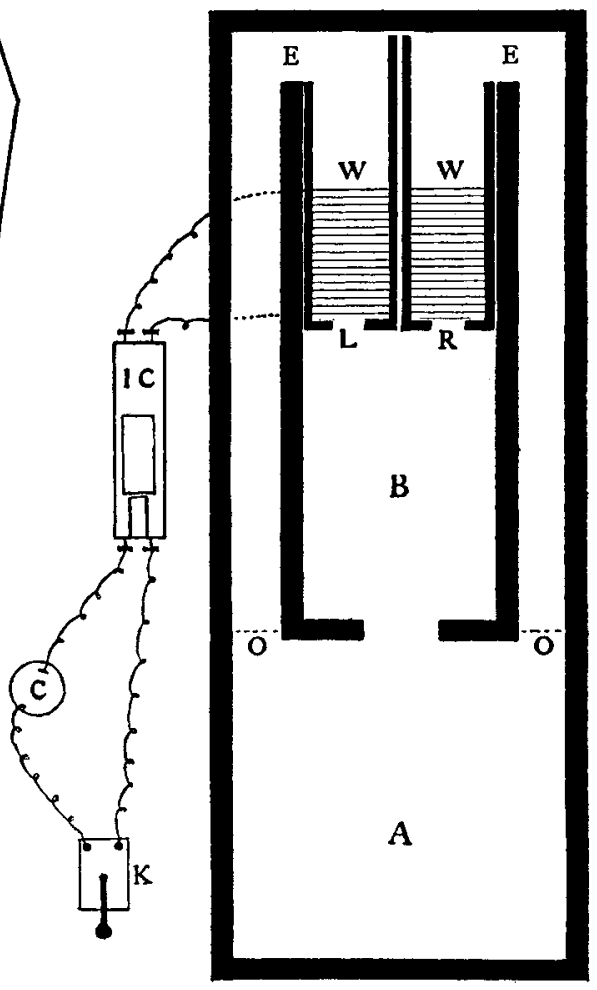

FIG. 2.

Fig. I. Discrimination box. $W$, electric box with white cardboards; $B$, electric box with black card. boards.

Fig. 2. Ground plan of discrimination box. $A$, nest-box; $B$, entrance chamber; $W W$, electric boxes; $L$, doorway of left electric box; $R$, doorway of right electric box; $E$, exit from electric box to alley; $O$, swinging door between alley and $A ; I C$, induction apparatus; $C$, electric battery; $K$, key in circuit.

into a nest-box, $A$, (fig. 2) an entrance chamber, $B$, and two electric boxes, $W, W$, together with alleys which connected these boxes with the nest-box. The doorways between the electric boxes and the alleys were 5 by $5 \mathrm{~cm}$. On the floor of each electric box, as is shown in the figures, were the wires of an interrupted circuit 
which could be completed by the experimenter, by closing the key $K$, whenever the feet of a mouse rested upon any two adjacent wires in either of the boxes. In this circuit were an electric battery and a Porter inductorium. One of these electric boxes bore black cards, and the other white cards similarly arranged. Each box bore two cards. One was at the entrance on the out-

TABLE I.

Positions of white cardboards for two preference series and twenty-five training series.

\begin{tabular}{|c|c|c|c|c|c|c|c|c|c|c|}
\hline & \multirow[t]{2}{*}{ I } & \multirow[t]{2}{*}{2} & \multirow[t]{2}{*}{3} & \multirow[t]{2}{*}{4} & \multirow[t]{2}{*}{5} & \multirow[t]{2}{*}{6} & \multirow[t]{2}{*}{7} & \multirow[t]{2}{*}{8} & \multirow[t]{2}{*}{9} & \multirow[t]{2}{*}{10} \\
\hline Series $\downarrow$ & & & & & & & & & & \\
\hline A & $i$ & $\mathbf{r}$ & 1 & $\mathrm{r}$ & 1 & I & 1 & r & 1 & $\mathbf{r}$ \\
\hline B & $\mathbf{r}$ & 1 & $r$ & 1 & $\mathbf{r}$ & 1 & $\mathrm{r}$ & 1 & $\mathbf{r}$ & 1 \\
\hline I & $r$ & 1 & $\mathbf{r}$ & 1 & $r$ & 1 & $\mathbf{r}$ & 1 & $\mathbf{r}$ & 1 \\
\hline 2 & 1 & 1 & r & $\mathrm{r}$ & 1 & $\mathrm{r}$ & i & $i$ & $\mathbf{r}$ & $\mathbf{r}$ \\
\hline 3 & $r$ & $\mathbf{r}$ & 1 & $\mathbf{r}$ & 1 & 1 & $r$ & 1 & $\mathbf{r}$ & 1 \\
\hline 4 & 1 & 1 & 1 & $\mathrm{r}$ & $\mathbf{r}$ & $\mathrm{r}$ & 1 & $r$ & $\mathbf{r}$ & 1 \\
\hline 5 & $\mathbf{r}$ & 1 & $\mathbf{r}$ & 1 & $\mathbf{r}$ & 1 & $\mathbf{r}$ & 1 & $\mathbf{r}$ & 1 \\
\hline 6 & 1 & 1 & $\mathbf{r}$ & 1 & $r$ & $\mathbf{r}$ & 1 & $\mathrm{r}$ & l & I \\
\hline 7 & $\mathbf{r}$ & 1 & 1 & 1 & $\mathbf{r}$ & $r$ & $x$ & 1 & $r$ & 1 \\
\hline 8 & $r$ & $r$ & 1 & 1 & $\mathrm{r}$ & 1 & $\mathbf{r}$ & 1 & $r$ & 1 \\
\hline 9 & $\mathbf{r}$ & $r$ & $\mathbf{r}$ & 1 & 1 & 1 & $r$ & 1 & $\mathbf{r}$ & 1 \\
\hline IO & 1 & 1 & I & 1 & $\mathbf{r}$ & $\mathbf{r}$ & $r$ & $r$ & 1 & $\mathbf{r}$ \\
\hline II & $\mathbf{r}$ & 1 & $\mathbf{r}$ & $r$ & $r$ & 1 & 1 & 1 & $r$ & 1 \\
\hline 12 & $\mathbf{r}$ & 1 & $\mathbf{r}$ & 1 & $r$ & $\mathbf{r}$ & 1 & 1 & $\mathbf{r}$ & 1 \\
\hline $1_{3}$ & $\mathrm{r}$ & 1 & $r$ & 1 & 1 & 1 & $\mathbf{r}$ & $\mathrm{r}$ & $\mathbf{r}$ & 1 \\
\hline 14 & 1 & 1 & 1 & 1 & $\mathrm{r}$ & $\mathbf{r}$ & $r$ & $x$ & 1 & $\mathbf{r}$ \\
\hline 15 & $r$ & 1 & $\mathbf{r}$ & $I$ & $r$ & 1 & 1 & 1 & $r$ & 1 \\
\hline 16 & 1 & $r$ & 1 & 1 & 1 & $\mathbf{r}$ & $\mathbf{r}$ & $\mathrm{r}$ & 1 & $\mathrm{r}$ \\
\hline 17 & $r$ & $\mathbf{I}$ & $r$ & $r$ & 1 & 1 & 1 & 1 & $r$ & 1 \\
\hline $\begin{array}{l}1 \\
18\end{array}$ & 1 & $\mathbf{r}$ & i & $\mathrm{I}$ & $\mathrm{r}$ & 1 & i & r & 1 & $\mathrm{r}$ \\
\hline 19 & $\mathbf{r}$ & 1 & $r$ & 1 & $\mathbf{r}$ & 1 & $\mathbf{r}$ & 1 & $\boldsymbol{r}$ & 1 \\
\hline 20 & 1 & 1 & 1 & $\mathrm{r}$ & 1 & $\mathbf{r}$ & 1 & $\mathrm{r}$ & $\mathbf{r}$ & $\mathrm{r}$ \\
\hline $2 I$ & $\mathbf{r}$ & 1 & I & $\mathbf{r}$ & $r$ & 1 & 1 & I & $\mathbf{r}$ & 1 \\
\hline 22 & 1 & 1 & $\mathrm{r}$ & $\mathrm{I}$ & I & 1 & $\mathbf{r}$ & r & $\overrightarrow{\mathbf{i}}$ & $\mathrm{r}$ \\
\hline 23 & $r$ & 1 & 1 & 1 & 1 & $\mathbf{I}$ & $\mathbf{r}$ & $x$ & $\mathbf{r}$ & 1 \\
\hline 24 & 1 & $\boldsymbol{I}$ & 1 & I & 1 & $\mathbf{r}$ & $\mathbf{r}$ & $\mathrm{I}$ & l & \\
\hline 25 & $I$ & $r$ & $\mathrm{r}$ & $\mathrm{r}$ & 1 & 1 & 1 & 1 & $\mathbf{r}$ & i \\
\hline
\end{tabular}

side of the box and the other on the inside, as fig. I indicates. The latter consisted of three sections of which two constituted linings for the sides of the box and the third a cover for a portion of the open top of the box. In no case did these inside cards extend the entire length of the electric boxes. The white and black cards were readily interchangeable, and they never were left on the same electric box for more than four consecutive tests. The 


\section{Fournal of Comparative Neurology and Psychology.}

order in which they were shifted during twenty-five series of ten tests each, in addition to the preference series $A$ and $B$, is given in table $I$. In case a mouse required more than twenty-five series of tests ( 250 tests), the same set of changes was repeated, beginning with series $\mathrm{I}$. In the table the letters $r$ and $l$ refer to the position of the white cards; $r$ indicates that they marked the electric box which was on the right of the mouse as it approached the entrances of the electric boxes from the nest-box; $l$ indicates that it marked the left electric box.

The way in which this apparatus was used may be indicated by a brief description of our experimental procedure. A dancer was placed in the nest-box by the experimenter, and thence it was permitted to pass into the entrance chamber, $B$. The experimenter then placed a piece of cardboard between it and the doorway between $A$ and $B$ and gradually narrowed the space in which the animal could move about freely by moving the cardboard toward the electric boxes. This, without in any undesirable way interfering with the dancer's attempts to discriminate and choose correctly, greatly lessened the amount of random activity which preceded choice. When thus brought face to face with the entrances to the boxes the mouse soon attempted to enter one of them. If it happened to select the white box it was permitted to enter, pass through, and return to the nest-box; but if, instead, it started to enter the black box the experimenter by closing the key, upon which his finger constantly rested during the tests, caused it to receive an electric shock which as a rule forced a hasty retreat from the black passage-way and the renewal of attempts to discover by comparison which box should be entered.

Each of the forty mice experimented with was given ten tests every morning until it succeeded in choosing the white box correctly on three consecutive days, that is for thirty tests. A choice was recorded as wrong if the mouse started to enter the black box and received a shock; as right if, either directly or after running from one entrance to the other a number of times, it entered the white box. Whether it entered the white electric box or the black one, it was permitted to return to the nest-box by way of the white box before another test given. Escape to the nest-box by way of the black box was not permitted. A male and a female, which were housed in the same cage between experiments, were placed in the experiment box together and given their tests turn about 
Almost all of the mice used were between six and eight weeks old at the beginning of their training. The exact age of each, together with its number, is stated in table 2. This table shows also the general classification of our experiments. They naturally fall into three sets. These are designated by the roman numerals

TABLE 2.

Age in days, at the beginning of training, of each mouse, with a statement of the conditions of training.

\begin{tabular}{|c|c|c|c|c|c|}
\hline \multirow{2}{*}{ Condition of discrimination. } & \multirow{2}{*}{$\begin{array}{l}\text { Strength of } \\
\text { stimulus. }\end{array}$} & \multicolumn{2}{|c|}{ Males. } & \multicolumn{2}{|c|}{ Females. } \\
\hline & & Number. & Age in days. & Number. & Age in days. \\
\hline Medium & $\begin{array}{c}\text { Weak } \\
125 \pm 10\end{array}$ & $\begin{array}{l}128 \\
134\end{array}$ & $\begin{array}{l}5^{\circ} \\
5^{\circ}\end{array}$ & $\begin{array}{l}\text { I27 } \\
\text { I33 }\end{array}$ & $\begin{array}{l}50 \\
43\end{array}$ \\
\hline Set I & $\begin{array}{c}\text { Medium } \\
300 \pm 25\end{array}$ & $\begin{array}{l}\text { I92 } \\
\text { I94 }\end{array}$ & $\begin{array}{l}47 \\
47\end{array}$ & $\begin{array}{l}191 \\
193\end{array}$ & $\begin{array}{l}47 \\
47\end{array}$ \\
\hline Medium & $\begin{array}{r}\text { Strong } \\
500 \pm 50\end{array}$ & $\begin{array}{l}130 \\
132 \\
\end{array}$ & $\begin{array}{l}3^{6} \\
44 \\
\end{array}$ & $\begin{array}{l}129 \\
13 \mathrm{I} \\
\end{array}$ & $\begin{array}{l}36 \\
37\end{array}$ \\
\hline & 135 & $\begin{array}{l}268 \\
274\end{array}$ & $\begin{array}{l}52 \\
50\end{array}$ & $\begin{array}{l}267 \\
269\end{array}$ & $\begin{array}{l}52 \\
5^{2}\end{array}$ \\
\hline Great & 195 & $\begin{array}{l}266 \\
418\end{array}$ & $\begin{array}{l}5^{\circ} \\
4^{8}\end{array}$ & $\begin{array}{l}263 \\
265\end{array}$ & $\begin{array}{l}5^{\circ} \\
50\end{array}$ \\
\hline Set II & 255 & $\begin{array}{l}260 \\
262\end{array}$ & $\begin{array}{l}43 \\
43\end{array}$ & $\begin{array}{l}259 \\
261\end{array}$ & $\begin{array}{l}43 \\
43\end{array}$ \\
\hline Easy & 375 & $\begin{array}{l}39^{6} \\
39^{8}\end{array}$ & $\begin{array}{l}48 \\
48\end{array}$ & $\begin{array}{l}189 \\
195\end{array}$ & $\begin{array}{l}4 \mathrm{I} \\
4 \mathrm{I}\end{array}$ \\
\hline & 420 & $\begin{array}{l}280 \\
412 \\
\end{array}$ & $\begin{array}{l}40 \\
74\end{array}$ & $\begin{array}{l}279 \\
281 \\
\end{array}$ & $\begin{array}{l}40 \\
43 \\
\end{array}$ \\
\hline Slight & 135 & 290 & 44 & I99 & 53 \\
\hline & 195 & 288 & 45 & 223 & 25 \\
\hline Set III & 255 & 286 & $4^{2}$ & 285 & 42 \\
\hline Difficult & 375 & 284 & 42 & 283 & 42 \\
\hline
\end{tabular}

I, II, and III in the table, and will throughout the paper be referred to as the experiments of set I, set II and set III. As is suggested by the heading "condition of discrimination," at the top of the first vertical column of table 2, these sets of experiments differ from one another first of all as to condition of visual discrimination or, more explicitly stated, in the amount by which the two electric 


\section{Fournal of Comparative Neurology and Psychology.}

boxes differed from one another in brightness. For set I this difference was medium, in comparison with later conditions, and discrimination was therefore of medium difficultness. For set II the difference was great, and discrimination was easy. For set III the difference was slight, and discrimination was difficult. It is clear, then, that the series of words, medium, great, slight, in the table refers to the amount by which the electric boxes differed in brightness, and the series medium, easy, difficult, to the demand made upon the visual discriminating ability of the mice.

For the sake of obtaining results in this investigation which should be directly comparable with those of experiments on the modifiability of behavior in the dancer which have been conducted during the past three years, it was necessary for us to use the same general method of controlling the visual conditions of the experiment that had previously been used. This we decided to do, notwithstanding the fact that we had before us methods which were vastly superior to the old one with respect to the describability of conditions and the accuracy and ease of their control. To any experimenter who wishes to repeat this investigation with other animals we should recommend that, before recourse is had to the use of cardboards for the purpose of rendering the boxes distinguishable, thorough tests be made of the ability of the animal to discriminate when the boxes are rendered different in brightness by the use of a screen which excludes a measurable amount of light from one of them. We have discovered that the simplest and best method of arranging the conditions for such experiments with the dancer as are now to be described is to use two electric boxes which are alike in all respects and to control the amount of light which enters one of them from the top. It is easy to obtain satisfactory screens and to measure their transmitting capacity. We regret that the first use which we wished to make of our results in this investigation forced us to employ conditions which are relatively complicated and difficult to describe.

For the sake of the scientific completeness of our paper, however, and not because we wish to encourage anyone to make use of the same conditions, we shall now describe as accurately as we may the conditions of visual discrimination in the several sets of experiments.

The cards at the entrances to the electric boxes were the same in all of the experiments. Each card (the black and the white) 
was $11.5 \mathrm{~cm}$. in height and $5.4 \mathrm{~cm}$. in width, with a hole 3.5 by $3.5 \mathrm{~cm}$. in the middle of its lower edge as is shown in fig. $\mathrm{I}$. These entrance cards were held in place by small metal carriers at the edges of the electric boxes. The area of white surface exposed to the view of a mouse as it approached the entrances to the electric boxes was $49.85 \mathrm{sq} . \mathrm{cm}$. and the same amount of black surface was exposed. The white cardboard reflected 10.5 times as much light as the black cardboard.

Special conditions of set $I$. The inside length of each electric box was $28.5 \mathrm{~cm}$. the width $7 \mathrm{~cm}$. and the depth $11.5 \mathrm{~cm}$. The inside cards extended from the inner edge of the front of each box a distance of $13.5 \mathrm{~cm}$. toward the back of the box. Consequently there was exposed to the view of the mouse a surface $13.5 \mathrm{~cm}$. by II $5 \mathrm{~cm}$. (the depth of the box and of the cardboard as well) on each side of the box. The section of cardboard at the top measured $13.5 \mathrm{~cm}$. in length by $6.5 \mathrm{~cm}$. in width. The total area of the white (or black) cardboard exposed on the inside of an electric box was therefore $13.5 \times 11.5 \times 2$ (the sides) +13.5 $\times 6.5$ (the top) $=398.25 \mathrm{sq}$. $\mathrm{cm}$. If to this we add the area of the entrance card we obtain $448.10 \mathrm{sq}$. $\mathrm{cm}$. as the amount of surface of cardboard carried by each electric box.

But another condition, in connection with the amount of cardboard present, determined the difference in the brightness of the boxes, namely, the amount of open space between the end of the inner cardboards and the end of the experiment box. The larger this opening the more light entered each box. In the case of the experiments of set $I$ this uncovered portion of each electric box was $15 \mathrm{~cm}$. long by $7 \mathrm{~cm}$. wide; its area, therefore, was $105 \mathrm{sq} . \mathrm{cm}$.

Special conditions of set $I I$. Both the outer and the inner cardboards were precisely the same in form and arrangement as in the case of set $I$, but in order that discrimination might be rendered easier, and the time required for the acquisition of the habit thus shortened, a hole $8.7 \mathrm{~cm}$. long by $3.9 \mathrm{~cm}$. wide was cut in the middle or top section of the white cardboard. This greatly increased the amount of light in the white electric box. The difference in the brightness of the boxes was still further increased by a reduction of the space between the end of the cardboard and the end of the box from $15 \mathrm{~cm}$. to $2 \mathrm{~cm}$. or, in terms of area, from $105 \mathrm{sq}$. $\mathrm{cm}$. to $\mathrm{I}_{4} \mathrm{sq} . \mathrm{cm}$. This was accomplished by cutting $13 \mathrm{~cm}$. from the rear end of the experiment box. For the experiments of set 
466 Fournal of Comparative Neurology and Psychology.

II the black box was much darker than it was for those of set I, whereas the white box was not markedly different in appearance.

Special conditions of set III. The experiments of this set were conducted with the visual conditions the same as in set II, except that there was no hole in the white cardboard over the electric box. This rendered the white box much darker than it was in the experiments of set II, consequently the two boxes differed less in brightness than in the case of set II, and discrimination was much more difficult than in the experiments of either of the other sets.

In the second column of table 2 the values of the several strengths of electrical stimuli used in the investigation are stated. To obtain our stimulus we used a storage cell, in connection with gravity batteries, and with the current from this operated a PORTER inductorium. The induced current from the secondary coil othis apparatus was carried by the wires which constituted an interrupted circuit on the floor of the electric boxes. For the experiments of set I the strengths of the stimuli used were not accurately determined, for we had not at that time discovered a satisfactory means of measuring the induced current. These experiments therefore served as a preliminary investigation whose chief value lay in the suggestions which it furnished for the planning of later experiments. The experiments of sets II and III were made with a PORTER inductorium which we had calibrated, with the help of Dr. E. G. Martin of the Harvard Medical School, by a method which he has recently devised and described..$^{2}$

On the basis of the calibration measurements which we made by Martin's method the curve of fig. 3 was plotted. From this curve it is possible to read directly in "units of stimulation" the value of the induced current which is yielded by a primary current of one ampere for any given position of the secondary coil. With the secondary coil at 0 , for example, the value of the induced current is $35^{\circ}$ units; with the secondary at 5.2 centimeters on the scale of the inductorium, its value is 155 units; and with the secondary at IO, its value is 12 units. The value of the induced current for a primary current greater or less than unity is obtained by multiplying the reading from the calibration curve by the value

\footnotetext{
2 Martin, E. G. A quantitative study of faradic stimulation. I. The variable factors involved. Amer. Four. of Physiol., vol. 22, pp. 61-74. 1908. II. The calibration of the inductorium for break shocks. Ibid., pp. 116-132.
} 
of the primary current. The primary current used for the experiments of sets II and III measured I.2 amperes, hence the value of the stimulating current which was obtained when the secondary coil stood at 0 was $35^{\circ} \times 1.2=420$ units of stimulation.

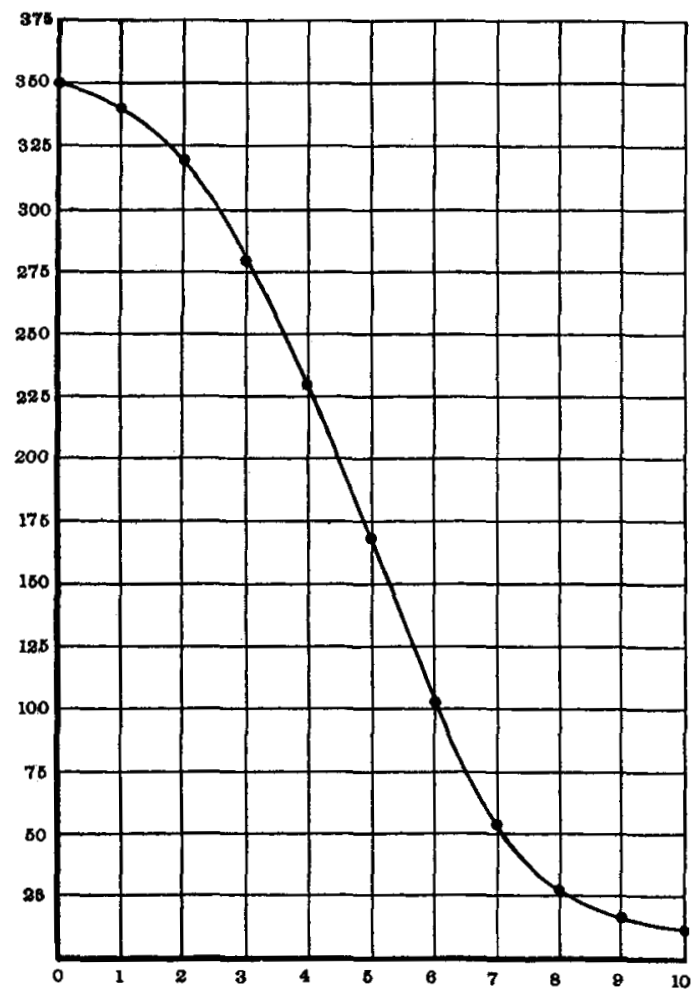

FıG. 3. Calibration curve for Porter inductorium. The numbers below the base line refer to the position of the secondary coil with reference to the primary. The positions are read, as on the scale of the inductorium, in centimeters. The numbers in the margin represent values of the induced current in terms of MARTIN's unit of stimulation.

As conditions for the experiments of set I, we chose three strengths of stimuli which we designated as weak, medium, and strong. The weak stimulus was slightly above the threshold of stimulation for the dancers. Comparison of the results which it yielded with those obtained by the use of our calibrated inductorium enable us to state with a fair degree of certainty that its value was I $25 \pm 10$ units of stimulation. The strong stimulus was decid- 
edly disagreeable to the experimenters and the mice reacted to it vigorously. Its value was subsequently ascertained to be 500 \pm 50 units. For the medium stimulus we tried to select a value which should be about midway between these extremes. In this we succeeded better than we could have expected to, for comparison indicated that the value was $300 \pm 25$ units. Fortunately for the interpretation of this set of results, the exact value of the stimuli is not important.

By the use of our calibrated inductorium and the measurement of our primary current, we were able to determine satisfactorily the stimulating values of the several currents which were used in the experiments of sets II and III. The primary current of I.2 amperes, which was employed, served to actuate the interrupter of the inductorium as well as to provide the stimulating current. The interruptions occurred at the rate of $65 \pm 5$ per second. We discovered at the outset of the work that it was not worth while to attempt to train the dancers with a stimulus whose value was much less than 135 units. We therefore selected this as our weakest stimulus. At the other extreme a stimulus of 420 units was as strong as we deemed it safe to employ. Between these two, three intermediate strengths were used in the case of set II, and two in the case of set III. Originally it had been our intention to make use of stimuli which varied from one another in value by 60 units of stimulation, beginning with $\mathrm{I} 35$ and increasing by steps of 60 through $195,255,315,375$ to as nearly 425 as possible. It proved to be needless to make tests with all of these.

We may now turn to the results of the experiments and the interpretation thereof. Before the beginning of its training each mouse was given two series of tests in which the electric shock was not used and return to the nest-box through either the white or the black box was permitted. These twenty tests (ten in series $A$ and ten in series B) have been termed preference tests, for they served to reveal whatever initial tendency a dancer possessed to choose the white or the black box. On the day following preference series $B$, the regular daily training series were begun and they were continued without interruption until the dancer had succeeded in choosing correctly in every test on three consecutive days.

Results of the experiments of set $I$. The tests with the weak stimulus of set I were continued for twenty days, and up to that time only one of the four individuals in training (no. 128) had 
acquired a perfect habit. On the twentieth day it was evident that the stimulus was too weak to furnish an adequate motive for the avoidance of the black box and the experiments were discontinued.

A few words in explanation of the tables are needed at this point. In all of the tables of detailed results the method of arrangement which is illustrated by table 3 was employed. At the top of the table are the numbers of the mice which were trained under

TABLE 3.

The results of the experiments of set I, stimulus weak ( $125 \pm$ Io units).

\begin{tabular}{|c|c|c|c|c|c|c|c|}
\hline \multirow{2}{*}{ Series. } & \multicolumn{3}{|c|}{ Males. } & \multicolumn{3}{|c|}{ Femaies. } & \multirow{2}{*}{$\begin{array}{c}\text { General } \\
\text { Average. }\end{array}$} \\
\hline & No. 128 & No. 134. & Average. & No. 127. & No. 133. & Average. & \\
\hline $\begin{array}{l}\text { A } \\
\text { B }\end{array}$ & $\begin{array}{l}6 \\
5\end{array}$ & $\begin{array}{l}7 \\
5\end{array}$ & $\begin{array}{l}6.5 \\
5.0\end{array}$ & $\begin{array}{l}4 \\
6\end{array}$ & $\begin{array}{l}5 \\
4\end{array}$ & $\begin{array}{l}4 \cdot 5 \\
5 \cdot 0\end{array}$ & $\begin{array}{l}5.50 \\
5.00\end{array}$ \\
\hline $\begin{array}{l}\text { I } \\
2\end{array}$ & $\begin{array}{l}3 \\
6\end{array}$ & $\begin{array}{l}5 \\
6\end{array}$ & $\begin{array}{l}4.0 \\
6.0\end{array}$ & $\begin{array}{l}4 \\
6\end{array}$ & $\begin{array}{l}4 \\
7\end{array}$ & $\begin{array}{l}4.0 \\
6.5\end{array}$ & $\begin{array}{l}4.00 \\
6.25\end{array}$ \\
\hline 3 & 5 & 4 & $4 \cdot 5$ & 2 & 5 & $3 \cdot 5$ & 4.00 \\
\hline 4 & 4 & 5 & $4 \cdot 5$ & 6 & 4 & 5.0 & 4.75 \\
\hline 5 & 3 & 7 & 5.0 & 3 & 5 & 4.0 & $4.5^{\circ}$ \\
\hline 6 & 2 & 5 & $3 \cdot 5$ & 4 & 4 & 4.0 & $3 \cdot 75$ \\
\hline $\begin{array}{l}7 \\
8\end{array}$ & $\begin{array}{l}3 \\
2\end{array}$ & $\begin{array}{l}4 \\
2\end{array}$ & $\begin{array}{l}3.5 \\
2.0\end{array}$ & $\begin{array}{l}4 \\
2\end{array}$ & $\begin{array}{l}7 \\
3\end{array}$ & $\begin{array}{l}5 \cdot 5 \\
2.5\end{array}$ & $\begin{array}{r}4.50 \\
2.25\end{array}$ \\
\hline 9 & 5 & 5 & 5.0 & 3 & 3 & 3.0 & 4.00 \\
\hline 10 & I & 2 & 1.5 & 4 & 2 & 3.0 & 2.25 \\
\hline II & 0 & 3 & I. 5 & 3 & 5 & 4.0 & 2.75 \\
\hline 12 & I & I & 1.0 & 3 & 2 & 2.5 & I. 75 \\
\hline 13 & I & 2 & I. 5 & 2 & 2 & 2.0 & I. 75 \\
\hline 14 & I & I & 1.0 & $\circ$ & 3 & 1. 5 & I.25 \\
\hline 15 & I & 3 & 2.0 & I & 3 & 2.0 & 2.00 \\
\hline 16 & 0 & 0 & o. & I & 0 & 0.5 & 0.25 \\
\hline 17 & 0 & I & 0.5 & 0 & 0 & 0. & 0.25 \\
\hline I8 & 0 & 0 & 0. & 2 & $\mathrm{Y}$ & 1.5 & 0.75 \\
\hline 19 & & I & 0.5 & 2 & I & 1.5 & 1.00 \\
\hline 20 & & 3 & $x .5$ & 2 & 3 & 2.5 & $2 . \infty$ \\
\hline
\end{tabular}

the conditions of stimulation named in the heading of the table. The first vertical column gives the series numbers, beginning with the preference series $A$ and $B$ and continuing from $I$ to the last series demanded by the experiment. In additional columns appear the number of errors made in each series of ten tests, day by day, by the several subjects of the experiments; the average number of errors made by the males in each series; the average number of errors made by the females; and, finally, the general 
470 Fournal of Comparative Neurology and Psychology.

average for both males and females. In table 3 , for example, it appears that male no. $\mathbf{I} 28$ chose the black box in preference to the white 6 times in series A, 5 times in series B, 3 times in series I, 6 times in series 2. After series 15 he made no errors during three consecutive series. His training was completed, therefore, on the eighteenth day, as the result of 180 tests. We may say, however, that only $15^{\circ}$ tests were necessary for the establishment of a perfect habit, for the additional thirty tests, given after the fifteenth series, served merely to reveal the fact that he already possessed a perfect habit. In view of this consideration, we shall

TABLE 4.

The results of the experiments of set I, stimulus medium (300 \pm 25 units).

\begin{tabular}{|c|c|c|c|c|c|c|c|}
\hline \multirow{2}{*}{ Series. } & \multicolumn{3}{|c|}{ Males. } & \multicolumn{3}{|c|}{ Females. } & \multirow{2}{*}{$\begin{array}{l}\text { General } \\
\text { Average. }\end{array}$} \\
\hline & No. 192. & No. 194. & Average. & No. I9I. & No. 193. & Average. & \\
\hline $\begin{array}{l}\text { A } \\
\text { B }\end{array}$ & $\begin{array}{l}4 \\
6\end{array}$ & $\begin{array}{l}8 \\
6\end{array}$ & $\begin{array}{l}6.0 \\
6.0\end{array}$ & $\begin{array}{l}3 \\
4\end{array}$ & $\begin{array}{l}7 \\
6\end{array}$ & $\begin{array}{l}5.0 \\
5.0\end{array}$ & $\begin{array}{l}5 \cdot 5^{\circ} \\
5 \cdot 5^{\circ}\end{array}$ \\
\hline I & 4 & 4 & 4.0 & 4 & 5 & $4 \cdot 5$ & 4.25 \\
\hline 2 & 3 & 3 & 3.0 & 4 & 2 & 3.0 & 3.00 \\
\hline 3 & 4 & 5 & $4 \cdot 5$ & 5 & 6 & $5 \cdot 5$ & $5 . \infty 0$ \\
\hline 4 & 3 & 4 & $3 \cdot 5$ & 6 & 3 & $4 \cdot 5$ & $4 . \infty 0$ \\
\hline 5 & 2 & 4 & 3.0 & 5 & 7 & 6.0 & $4.5^{\circ}$ \\
\hline 6 & 2 & 0 & 1.0 & 2 & 2 & 2.0 & 1.50 \\
\hline 7 & 2 & 2 & 2.0 & 0 & 3 & I. 5 & 1.75 \\
\hline 8 & I & 0 & 0.5 & I & 0 & 0.5 & 0.50 \\
\hline 9 & $\circ$ & 2 & 1.0 & 0 & 0 & o. & $0.5 \mathrm{r}$ \\
\hline 10 & 0 & 0 & 0. & 0 & 0 & 0. & 0. \\
\hline I I & 0 & o & o. & 0 & & o. & 0. \\
\hline I2 & & 0 & o. & & & & 0. \\
\hline
\end{tabular}

take as a measure of the rapidity of learning in these experiments the number of tests received by a mouse up to the point at which errors ceased for at least three consecutive series.

Precisely as the individuals of table 3 had been trained by the use of a weak stimulus, four other dancers were trained with a medium stimulus. The results appear in table 4. All of the subjects acquired a habit quickly. Comparison of these results with those obtained with the weak stimulus clearly indicates that the medium stimulus was much more favorable to the acquirement of the white-black visual discrimination habit.

In its results the strong stimulus proved to be similar to the weak stimulus. All of the mice in this case learned more slowly 
than did those which were trained with the medium strength of stimulus.

The general result of this preliminary set of experiments with three roughly measured strengths of stimulation was to indicate that neither a weak nor a strong electrical stimulus is as favorable to the acquisition of the white-black habit as is a medium stimulus.

TABLE 5.

The results of the experiments of set I, stimulus strong (500 \pm 50 units).

\begin{tabular}{|c|c|c|c|c|c|c|c|}
\hline \multirow{2}{*}{ Series. } & \multicolumn{3}{|c|}{ Males. } & \multicolumn{3}{|c|}{ Females. } & \multirow{2}{*}{$\begin{array}{l}\text { General } \\
\text { Average. }\end{array}$} \\
\hline & No. 130. & No. ${ }^{32}$. & Average. & No. 129. & No. ${ }^{1}{ }^{1}$. & Average. & \\
\hline $\begin{array}{l}\text { A } \\
\text { B }\end{array}$ & $\begin{array}{l}7 \\
6\end{array}$ & $\begin{array}{l}6 \\
4\end{array}$ & $\begin{array}{l}6.5 \\
5.0\end{array}$ & $\begin{array}{l}5 \\
4\end{array}$ & $\begin{array}{l}1 \\
4\end{array}$ & $\begin{array}{l}3.0 \\
4.0\end{array}$ & $\begin{array}{l}4 \cdot 75 \\
4 \cdot 5^{\circ}\end{array}$ \\
\hline $\begin{array}{r}1 \\
2 \\
3 \\
4 \\
5 \\
6 \\
7 \\
8 \\
9 \\
10 \\
11 \\
12 \\
13 \\
14 \\
15 \\
16 \\
17 \\
18 \\
19 \\
20 \\
21 \\
22 \\
23\end{array}$ & $\begin{array}{l}3 \\
3 \\
5 \\
3 \\
2 \\
3 \\
3 \\
4 \\
3 \\
2 \\
1 \\
1 \\
1 \\
0 \\
2 \\
0 \\
0 \\
0 \\
0\end{array}$ & $\begin{array}{l}5 \\
1 \\
3 \\
2 \\
2 \\
1 \\
0 \\
0 \\
2 \\
3 \\
1 \\
2 \\
1 \\
0 \\
0 \\
0\end{array}$ & $\begin{array}{l}4.0 \\
2.0 \\
4.0 \\
2.5 \\
2.0 \\
2.0 \\
1.5 \\
2.0 \\
2.5 \\
2.5 \\
1.0 \\
1.5 \\
1.0 \\
0 . \\
1.0 \\
0 . \\
0 . \\
0 .\end{array}$ & $\begin{array}{l}5 \\
3 \\
3 \\
2 \\
2 \\
2 \\
2 \\
1 \\
2 \\
1 \\
2 \\
0 \\
2 \\
2 \\
0 \\
0 \\
0\end{array}$ & $\begin{array}{l}5 \\
3 \\
3 \\
3 \\
4 \\
2 \\
4 \\
2 \\
1 \\
1 \\
0 \\
0 \\
2 \\
2 \\
1 \\
2 \\
1 \\
2 \\
1 \\
1 \\
0 \\
0 \\
0\end{array}$ & $\begin{array}{l}5.0 \\
3.0 \\
3.0 \\
2.5 \\
3.0 \\
2.0 \\
3.0 \\
1.5 \\
1.5 \\
1.0 \\
1.0 \\
0 . \\
2.0 \\
2.0 \\
0.5 \\
1.0 \\
0.5 \\
1.0 \\
0.5 \\
0.5 \\
0 . \\
0 . \\
0 .\end{array}$ & $\begin{array}{l}4.50 \\
2.50 \\
3.50 \\
2.50 \\
2.50 \\
2.00 \\
2.25 \\
1.75 \\
2.00 \\
1.75 \\
1 . \infty \\
0.75 \\
1.50 \\
1.00 \\
0.75 \\
0.50 \\
0.25 \\
0.50 \\
0.25 \\
0.25 \\
0 . \\
0 . \\
0 .\end{array}$ \\
\hline
\end{tabular}

Contrary to our expectations, this set of experiments did not prove that the rate of habit-formation increases with increase in the strength of the electric stimulus up to the point at which the shock becomes positively injurious. Instead an intermediate range of intensity of stimulation proved to be most favorable to the acquisition of a habit under the conditions of visual discrimination of this set of experiments. 
472 Fournal of Comparative Neurology and Psychology.

In the light of these preliminary results we were able to plan a more exact and thoroughgoing examination of the relation of strength of stimulus to rapidity of learning. Inasmuch as the training under the conditions of set I required a great deal of time, we decided to shorten the necessary period of training by making the two electric boxes very different in brightness, and the discrimination correspondingly easy. This we did, as has already been explained, by decreasing the amount of light which entered the black box, while leaving the white box about the same. The influence of this change on the time of learning was very marked indeed.

With each of the five strengths of stimuli which were used in set II two pairs of mice were trained, as in the case of set I. The detailed results of these five groups of experiments are presented in tables 6 to 10. Casual examination of these tables reveals the fact that in general the rapidity of learning in this set of experiments increased as the strength of the stimulus increased. The weakest stimulus ( 135 units) gave the slowest rate of learning; the strongest stimulus ( 420 units), the most rapid.

TABLE 6.

The results of the experiments of set II, stimulus 135 units.

\begin{tabular}{|c|c|c|c|c|c|c|c|}
\hline \multirow{2}{*}{ Series. } & \multicolumn{3}{|c|}{ Malixs. } & \multicolumn{3}{|c|}{ Females. } & \multirow{2}{*}{$\begin{array}{c}\text { General } \\
\text { Average. }\end{array}$} \\
\hline & No. 268. & No. 274 . & Average. & No. 267 . & No. 269 . & Average. & \\
\hline $\begin{array}{l}\text { A } \\
\text { B }\end{array}$ & $\begin{array}{l}9 \\
8\end{array}$ & $\begin{array}{l}7 \\
6\end{array}$ & $\begin{array}{l}8.0 \\
7.0\end{array}$ & $\begin{array}{l}8 \\
4\end{array}$ & $\begin{array}{l}7 \\
6\end{array}$ & $\begin{array}{l}7.5 \\
5.0\end{array}$ & $\begin{array}{l}7.75 \\
6.00\end{array}$ \\
\hline I & 6 & 4 & 5.0 & 6 & 4 & 5.0 & 5.00 \\
\hline 2 & 2 & 3 & 2.5 & 2 & 4 & 3.0 & 2.75 \\
\hline 3 & 2 & 4 & 3.0 & 4 & 6 & 5.0 & 4.0 \\
\hline 4 & I & 4 & 2.5 & $\circ$ & I & 0.5 & $1.5^{\circ}$ \\
\hline 5 & - & 3 & I. 5 & 2 & 2 & 2.0 & 1.75 \\
\hline 6 & $\circ$ & 2 & 1.0 & 0 & 0 & 0. & $0.5^{\circ}$ \\
\hline 7 & $\circ$ & I & 0.5 & I & $I$ & 1.0 & 0.75 \\
\hline 8 & & $\circ$ & o. & $\circ$ & $\circ$ & o. & o. \\
\hline 9 & & $\circ$ & 0. & $\circ$ & $\circ$ & 0. & 0. \\
\hline 10 & & ० & o. & 2 & $\circ$ & 1.0 & $0.5^{\circ}$ \\
\hline II & & & & I & & 0.5 & 0.25 \\
\hline 12 & & & & I & & 0.5 & 0.25 \\
\hline 13 & & & & $\circ$ & & o. & o. \\
\hline 14 & & & & $\circ$ & & o. & \\
\hline 15 & & & & 1 & & 0.5 & 0.25 \\
\hline 17 & & & & 0 & & $\begin{array}{l}0 . \\
0 .\end{array}$ & $\begin{array}{l}0 . \\
0 .\end{array}$ \\
\hline 18 & & & & 0 & & 0. & 0. \\
\hline
\end{tabular}


TABLE 7.

The results of the experiments of set II, stimulus I 95 units.

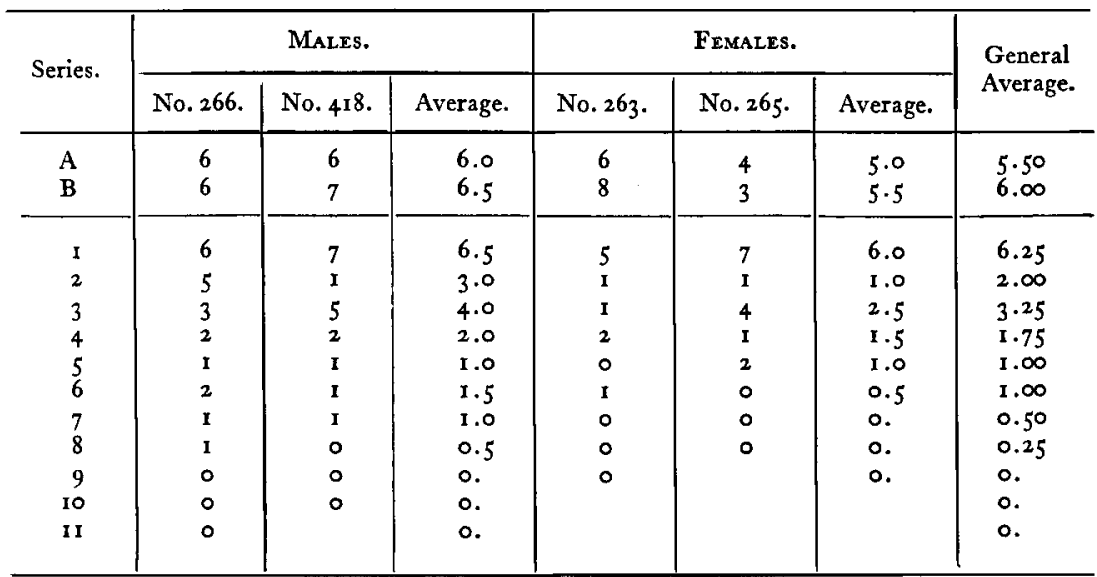

TABLE 8.

The results of the experiments of set II, stimulus 255 units.

\begin{tabular}{|c|c|c|c|c|c|c|c|}
\hline \multirow{2}{*}{ Series. } & \multicolumn{3}{|c|}{ Males. } & \multicolumn{3}{|c|}{ Females. } & \multirow{2}{*}{$\begin{array}{r}\text { General } \\
\text { Average. }\end{array}$} \\
\hline & No. 260. & No. 262. & Average. & No. 259. & No. $26 \mathrm{I}$. & Average. & \\
\hline $\begin{array}{l}\text { A } \\
\text { B }\end{array}$ & $\begin{array}{l}5 \\
7\end{array}$ & $\begin{array}{l}5 \\
6\end{array}$ & $\begin{array}{l}5.0 \\
6.5\end{array}$ & $\begin{array}{l}5 \\
5\end{array}$ & $\begin{array}{l}6 \\
5\end{array}$ & $\begin{array}{l}5.5 \\
5.0\end{array}$ & $\begin{array}{l}5 \cdot 25 \\
5 \cdot 75\end{array}$ \\
\hline $\begin{array}{r}1 \\
2 \\
3 \\
4 \\
5 \\
6 \\
7 \\
8 \\
9 \\
10 \\
11\end{array}$ & $\begin{array}{l}6 \\
4 \\
1 \\
0 \\
0 \\
0\end{array}$ & $\begin{array}{l}7 \\
7 \\
4 \\
2 \\
2 \\
0 \\
0 \\
0\end{array}$ & $\begin{array}{l}6.5 \\
5.5 \\
2.5 \\
1.0 \\
1.0 \\
0 . \\
0 . \\
0 .\end{array}$ & $\begin{array}{l}9 \\
4 \\
3 \\
4 \\
0 \\
0 \\
0\end{array}$ & $\begin{array}{l}3 \\
3 \\
1 \\
0 \\
2 \\
1 \\
1 \\
1 \\
0 \\
0 \\
0\end{array}$ & $\begin{array}{l}6.0 \\
3.5 \\
2.0 \\
2.0 \\
1.0 \\
0.5 \\
0.5 \\
0.5 \\
0 . \\
0 . \\
0 .\end{array}$ & $\begin{array}{l}6.25 \\
4.50 \\
2.25 \\
1.75 \\
1.00 \\
0.25 \\
0.25 \\
0.25 \\
0 . \\
0 . \\
0 .\end{array}$ \\
\hline
\end{tabular}


474 Fournal of Comparative Neurology and Psychology.

TABLE 9.

The results of the experiments of set II, stimulus 375 units.

\begin{tabular}{|c|c|c|c|c|c|c|c|}
\hline \multirow{2}{*}{ Series. } & \multicolumn{3}{|c|}{ Males. } & \multicolumn{3}{|c|}{ Females. } & \multirow{2}{*}{$\begin{array}{l}\text { General } \\
\text { Average }\end{array}$} \\
\hline & No. 396 . & No. $39^{8}$. & Average. & No. 189. & No. 195. & Average. & \\
\hline $\begin{array}{l}\text { A } \\
\text { B }\end{array}$ & $\begin{array}{l}6 \\
5\end{array}$ & $\begin{array}{l}6 \\
3\end{array}$ & $\begin{array}{l}6.0 \\
4.0\end{array}$ & $\begin{array}{l}6 \\
5\end{array}$ & $\begin{array}{l}7 \\
6\end{array}$ & $\begin{array}{l}6.5 \\
5.5\end{array}$ & $\begin{array}{l}6.25 \\
4.75\end{array}$ \\
\hline $\begin{array}{r}1 \\
2 \\
3 \\
4 \\
5 \\
6 \\
7 \\
8 \\
9 \\
10 \\
11 \\
12\end{array}$ & $\begin{array}{l}6 \\
5 \\
5 \\
0 \\
0 \\
0\end{array}$ & $\begin{array}{l}6 \\
1 \\
3 \\
4 \\
3 \\
0 \\
1 \\
0 \\
1 \\
0 \\
0 \\
0\end{array}$ & $\begin{array}{l}6.0 \\
3.0 \\
4.0 \\
2.0 \\
1.5 \\
0 . \\
0.5 \\
0 . \\
0.5 \\
0 . \\
0 . \\
0 .\end{array}$ & $\begin{array}{l}4 \\
5 \\
8 \\
3 \\
1 \\
0 \\
0 \\
0\end{array}$ & $\begin{array}{l}5 \\
3 \\
2 \\
1 \\
4 \\
0 \\
0 \\
0\end{array}$ & $\begin{array}{l}4.5 \\
4.0 \\
5.0 \\
2.0 \\
2.5 \\
0 . \\
0 . \\
0 .\end{array}$ & $\begin{array}{c}5.25 \\
3.50 \\
4.50 \\
2.00 \\
2.00 \\
0 . \\
.25 \\
0 . \\
.25 \\
0 . \\
0 . \\
0 .\end{array}$ \\
\hline
\end{tabular}

TABLE 10.

The results of the experiments of set II, stimulus 420 units.

\begin{tabular}{c|c|c|c|c|c|c|c}
\hline \multirow{2}{*}{ Series. } & \multicolumn{3}{|c|}{ Males. } & \multicolumn{3}{c|}{ FEMales. } & $\begin{array}{c}\text { General. } \\
\text { Average. }\end{array}$ \\
\cline { 2 - 7 } & No. 280. & No. 412. & Average. & No. 279. & No. 281. & Average. & \\
\hline A & 5 & 5 & 5.0 & 4 & 6 & 5.0 & $5 . \infty$ \\
B & 6 & 6 & 6.0 & 6 & 4 & 5.0 & 5.50 \\
\hline & & & & & & & \\
I & 5 & 5 & 5.0 & 5 & 5 & 5.0 & $5 . \infty$ \\
2 & 4 & 5 & 4.5 & 1 & 0 & 0.5 & 2.50 \\
3 & 2 & 5 & 3.5 & 2 & 4 & 3.0 & 3.25 \\
4 & 1 & 3 & 2.0 & 0 & 2 & 1.0 & 1.50 \\
5 & 0 & 3 & 1.5 & 0 & 1 & 0.5 & 2.0 \\
6 & 0 & 0 & 0. & 0 & 0 & 0. & 0. \\
7 & 0 & 0 & 0. & & 0 & 0. & 0. \\
8 & & 0 & 0. & & 0 & 0. & 0. \\
\hline
\end{tabular}

The results of the second set of experiments contradict those of the first set. What does this mean? It occurred to us that the apparent contradiction might be due to the fact that discrimination was much easier in the experiments of set II than in those of set I. To test this matter we planned to use in our third ser of experiments a condition of visual discrimination which should be extremely difficult for the mice. The reader will bear in mind that for set 
II the difference in brightness of the electric boxes was great; that for set III it was slight; and for set I, intermediate or medium.

For the experiments of set III only one pair of dancers was trained with any given strength of stimulus. The results, however, are not less conclusive than those of the other sets of experiments because of the smaller number of individuals used. The data of tables I I to I4 prove conclusively that our supposition was correct. The varying results of the three sets of experiments are explicable in terms of the conditions of visual discrimination. In

TABLE II.

The results of the experiments of set III, stimulus I 35 units.
TABLE 12.

The results of the experiments of set III, stimulus I95 units.

\begin{tabular}{|c|c|c|c|c|c|c|}
\hline \multirow{2}{*}{ Series. } & MaLe. & Female. & \multirow{2}{*}{ Average. } & Male. & FEMALE. & \multirow{2}{*}{ Average. } \\
\hline & No. 290. & No. 199. & & No. 288 . & No. 223. & \\
\hline $\begin{array}{l}\text { A } \\
\text { B }\end{array}$ & $\begin{array}{l}6 \\
4\end{array}$ & $\begin{array}{l}4 \\
7\end{array}$ & $\begin{array}{l}5.0 \\
5.5\end{array}$ & $\begin{array}{l}4 \\
7\end{array}$ & $\begin{array}{l}4 \\
8\end{array}$ & $\begin{array}{l}4.0 \\
7 \cdot 5\end{array}$ \\
\hline $\begin{array}{r}1 \\
2 \\
3 \\
4 \\
5 \\
6 \\
7 \\
8 \\
9 \\
10 \\
11 \\
12 \\
13 \\
14 \\
15 \\
16 \\
17\end{array}$ & $\begin{array}{l}4 \\
5 \\
3 \\
4 \\
7 \\
4 \\
7 \\
7 \\
4 \\
4 \\
4 \\
5 \\
3 \\
2 \\
4 \\
3 \\
2\end{array}$ & $\begin{array}{l}6 \\
2 \\
6 \\
2 \\
4 \\
4 \\
7 \\
5 \\
4 \\
2 \\
1 \\
3 \\
2 \\
4 \\
3 \\
0 \\
2\end{array}$ & $\begin{array}{l}5.0 \\
3.5 \\
4 \cdot 5 \\
3.0 \\
5 \cdot 5 \\
4.0 \\
7.0 \\
6.0 \\
4.0 \\
3.0 \\
2.5 \\
4.0 \\
2.5 \\
3.0 \\
3.5 \\
1.5 \\
2.0\end{array}$ & $\begin{array}{l}5 \\
3 \\
5 \\
6 \\
6 \\
4 \\
5 \\
2 \\
0 \\
3 \\
2 \\
1 \\
1 \\
0 \\
0 \\
0\end{array}$ & $\begin{array}{l}7 \\
6 \\
6 \\
3 \\
7 \\
4 \\
3 \\
2 \\
0 \\
1 \\
1 \\
0 \\
0 \\
0\end{array}$ & $\begin{array}{l}6.0 \\
4.5 \\
5.5 \\
4.5 \\
6.5 \\
4.0 \\
4.0 \\
2.0 \\
0 . \\
2.0 \\
1.5 \\
0.5 \\
0.5 \\
0 . \\
0 . \\
0 .\end{array}$ \\
\hline 18 & 0 & 2 & $x .0$ & & & \\
\hline I9 & I & I & I.O & & & \\
\hline 20 & 3 & 3 & 3.0 & & & \\
\hline $2 I$ & I & I & 1.0 & & & \\
\hline 22 & I & 0 & 0.5 & & & \\
\hline 23 & 2 & 0 & 1.0 & & & \\
\hline 24 & I & o & 0.5 & & & \\
\hline $\begin{array}{l}25 \\
26\end{array}$ & $\begin{array}{l}3 \\
I\end{array}$ & & $\begin{array}{l}1.5 \\
0.5\end{array}$ & & & \\
\hline 27 & I & & 0.5 & & & \\
\hline 28 & 0 & & o. & & & \\
\hline 29 & 0 & & o. & & & \\
\hline 30 & 2 & & 1.0 & & & \\
\hline
\end{tabular}


476 Fournal of Comparative Neurology and Psychology.

TABLE 13.

TABLE 14.

The results of the experiments of set III, The results of the experiments of set stimulus 255 units.

III, stimulus 375 units.

\begin{tabular}{|c|c|c|c|c|c|c|}
\hline \multirow{2}{*}{ Series. } & Male. & Frmale. & & Male. & Female. & \multirow{2}{*}{ Average. } \\
\hline & No. 286 . & No. 285. & Average. & No. 284 . & No. ${ }^{283}$. & \\
\hline $\begin{array}{l}\text { A } \\
\text { B }\end{array}$ & $\begin{array}{l}4 \\
4\end{array}$ & $\begin{array}{l}7 \\
5\end{array}$ & $\begin{array}{l}5 \cdot 5 \\
4 \cdot 5\end{array}$ & $\begin{array}{l}4 \\
3\end{array}$ & $\begin{array}{l}5 \\
4\end{array}$ & $\begin{array}{l}4.5 \\
3.5\end{array}$ \\
\hline I & 5 & 6 & $5 \cdot 5$ & 6 & 6 & 6.0 \\
\hline 2 & 3 & 3 & 3.0 & 3 & 2 & 2.5 \\
\hline 3 & 2 & 3 & 2.5 & 4 & 3 & 3.5 \\
\hline 4 & 5 & 5 & 5.0 & 4 & 2 & 3.0 \\
\hline 5 & 2 & 4 & 3.0 & 2 & 5 & $3 \cdot 5$ \\
\hline 6 & 2 & 3 & 2.5 & 3 & 2 & 2.5 \\
\hline 7 & 3 & 2 & 2.5 & 6 & 5 & $5 \cdot 5$ \\
\hline 8 & I & $\mathbf{I}$ & 1.0 & 4 & 2 & 3.0 \\
\hline 9 & I & 2 & I. 5 & I & I & I.0 \\
\hline 10 & 2 & $\mathbf{I}$ & I. 5 & I & 2 & I. 5 \\
\hline II & 2 & 3 & 2.5 & I & 2 & I. 5 \\
\hline 12 & 3 & 0 & 1.5 & 3 & I & 2.0 \\
\hline 13 & 2 & o & 1.0 & I & I & 1.0 \\
\hline 14 & 0 & I & 0.5 & I & I & 1.0 \\
\hline 15 & 3 & I & 2.0 & I & 0 & 0.5 \\
\hline 16 & I & 。 & 0.5 & I & $I$ & 1.0 \\
\hline 17 & 。 & $\circ$ & o. & $\circ$ & I & 0.5 \\
\hline 18 & 。 & $\circ$ & o. & o & r & 0.5 \\
\hline 19 & $\circ$ & & o. & $\circ$ & I & 0.5 \\
\hline 20 & & & & & $\circ$ & 0. \\
\hline 21 & & & & & 2 & I.0 \\
\hline 22 & & & & & $\circ$ & o. \\
\hline 23 & & & & & 2 & 1.0 \\
\hline 24 & & & & & $\circ$ & o. \\
\hline 25 & & & & & 0 & 0. \\
\hline & & & & & & \\
\hline
\end{tabular}

set III both the weak and the strong stimuli were less favorable to the acquirement of the habit than the intermediate stimulus of I95 units. It should be noted that our three sets of experiments indicate that the greater the brightness difference of the electric boxes the stronger the stimulus which is most favorable to habitformation (within limits which have not been determined). Further discussion of the results and attempts to interpret them may be postponed until certain interesting general features of the work have been mentioned.

The behavior of the dancers varied with the strength of the stimulus to which they were subjected. They chose no less quickly in the case of the strong stimuli than in the case of the weak, but they were less careful in the former case and chose with less delib- 


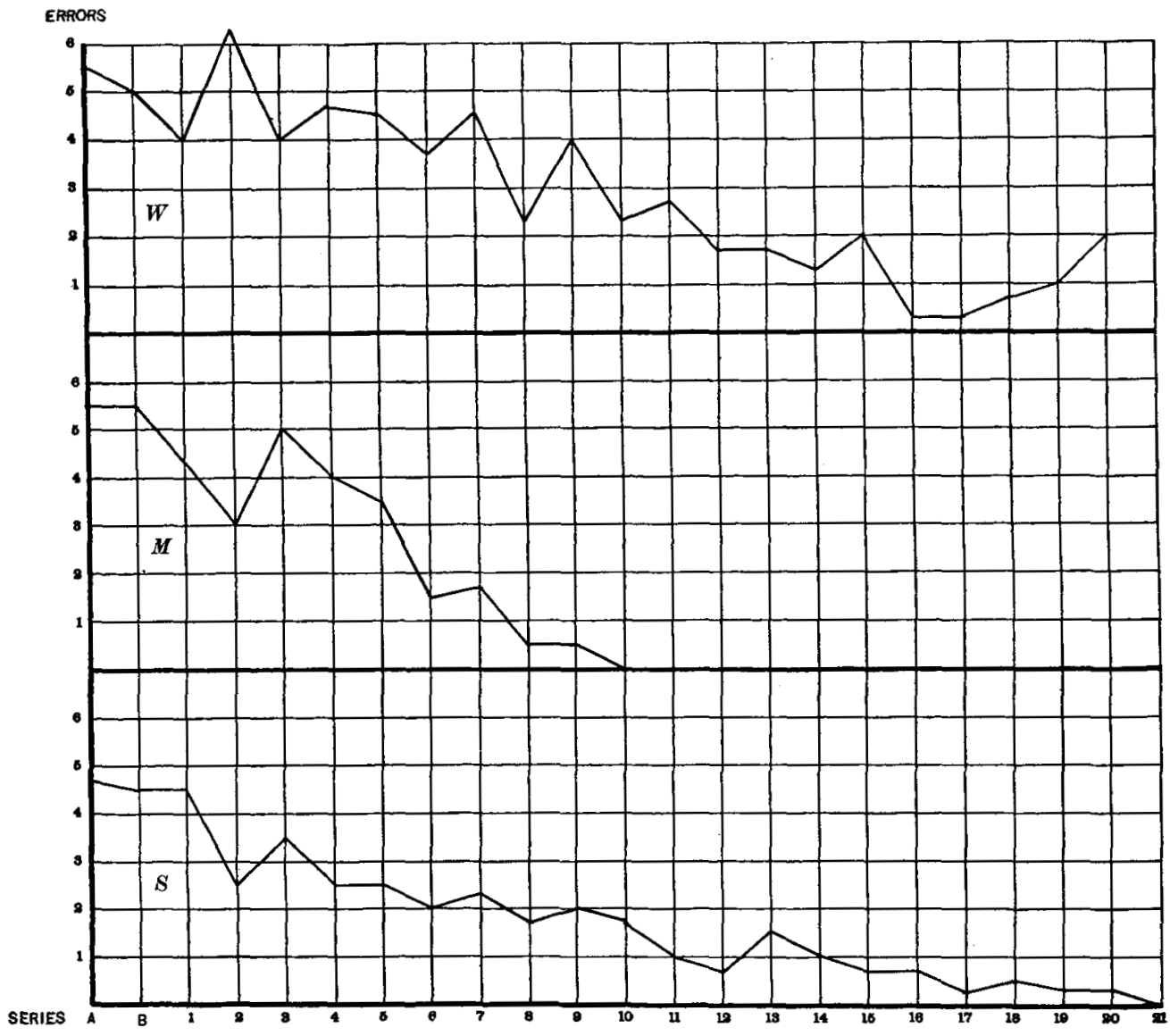

Fig. 4. Curves of learning. Ordinates represent series of ten tests each, and abscissæ represent the average number of errors for four mice in each series. $W$, designates the error curve for the individuals which were trained under the condition of weak electrical stimulation; $M$, designates the corresponding curve for the medium strength of stimulation; and $S$, that for the strong stimulus. 


\section{Fournal of Comparative Neurology and Psychology.}

eration and certainty. Fig. 4 exhibits the characteristic differences in the curves of learning yielded by weak, medium, and strong stimuli. These three curves were plotted on the basis of the average number of errors for the mice which were trained in the experiments of set I. Curve $W$ is based upon the data of the last column of table 3 , curve $M$, upon the data in the last column of table 4 ; and curve $S$ upon the data of the last column of table 5 . In addition to exhibiting the fact that the medium stimulus yielded a perfect habit much more quickly than did either of the other stimuli, fig. 4 shows a noteworthy difference in the forms of the curves for the weak and the strong stimuli. Curve $W$ (weak stimulus) is higher throughout its course than is curve $S$ (strong stimulus). This means that fewer errors are made from the start under the condition of strong stimulation than under the condition of weak stimulation.

Although by actual measurement we have demonstrated marked difference in sensitiveness to the electric shock among our mice, we are convinced that these differences do not invalidate the conclusions which we are about to formulate in. the light of the results that have been presented. Determination of the threshold electric stimulus for twenty male and twenty female dancers proved that the males respond to a stimulus which is about Io per cent less than the smallest stimulus to which the females respond.

Table I 5 contains the condensed results of our experiments. It gives, for each visual condition and strength of stimulus, the number of tests required by the various individuals for the acquisition of a perfect habit; the average number of tests required by the males, for any given visual and electrical conditions; the same for the females; and the general averages. Although the numbers of the mice are not inserted in the table they may readily be learned if anyone wishes to identify a particular individual, by referring to the tables of detailed results. Under set I, weak stimulus, for example, table 15 gives as the records of the two males used $15^{\circ}$ and $200+$ tests. By referring to table 3, we discover that male no. I 28 acquired his habit as a result of 150 tests, whereas male no. I 34 was imperfect at the end of 200 tests. To indicate the latter fact the plus sign is added in table 15 . Of primary importance for the solution of the problem which we set out to study are the general averages in the last column of the table. From this series of averages we have constructed the curves of fig. 5. This figure 


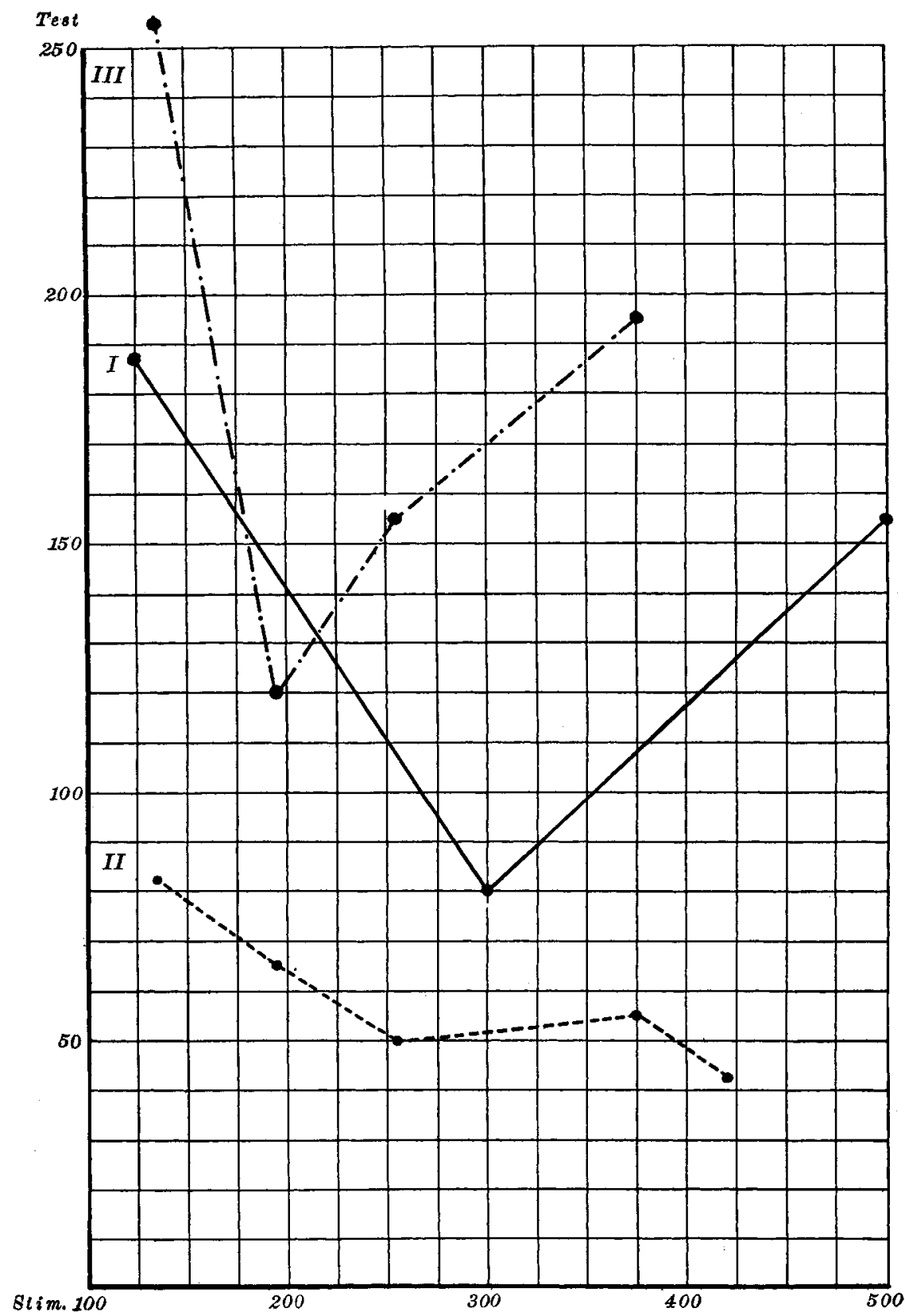

FIG. 5. A graphic representation of the relation of strength of electrical stimulus to condition of visual discrimination and rapidity of learning. Ordinates represent value of electric stimulus in units of stimulation; abscissæ represent the number of tests given. Curve $I$ represents the results of the experiments of Set I. Each dot indicates a value of stimulus which was used in the experiments. For example, the first dot to the left in curve $I$ signifies that the stimulus whose value was 125 units gave a perfect habit, in the case of the four individuals trained, with 187 tests; the second dot, that for the stimulus value of 300 units 80 tests were necessary; and the third that for the stimulus value of 500,155 tests. Curves II and III similarly represent the results of the experiments of sets II and III, respectively. 
480 Fournal of Comparative Neurology and Psychology.

very clearly and briefly presents the chiefly significant results of our investigation of the relation of strength of electrical stimulus to rate of habit-formation, and it offers perfectly definite answers to the questions which were proposed for solution.

In this figure the ordinates represent stimulus values, and the abscissæ number of tests. The roman numerals $I, I I, I I I$, designate, respectively, the curves for the results of set I, set II, and set III. Dots on the curves indicate the strengths of stimuli which were employed. Curve I for example, shows that a strength of stimulus of 300 units under the visual conditions of set I, yielded a perfect habit with 80 tests.

TABLE I5.

The number of tests required by the mice for the acquisition of a perfect habit of discrimination.

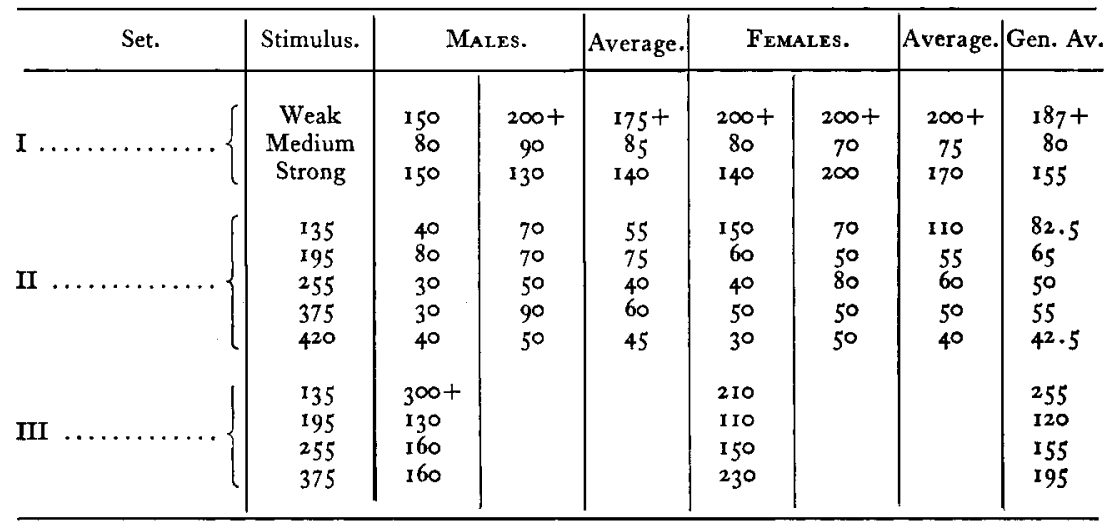

From the data of the various tables we draw the following conclusions:

I. In the case of the particular habit which we have studied, the rapidity of learning increases as the amount of difference in the brightness of the electric boxes between which the mouse is required to discriminate is increased. The limits within which this statement holds have not been determined. The higher the curves of fig. 5 stand from the base line, the larger the number of tests represented by them. Curve II is lowest, curve I comes next, and curve III is highest. It is to be noted that this is the order of increasing difficultness of discrimination in the three sets of experiments. 
2. The relation of the strength of electrical stimulus to rapidity of learning or habit-formation depends upon the difficultness of the habit, or, in the case of our experiments, upon the conditions of visual discrimination.

3. When the boxes which are to be discriminated between differ very greatly in brightness, and discrimination is easy, the rapidity of learning increases as the strength of the electrical stimulus is increased from the threshold of stimulation to the point of harmful intensity. This is indicated by curve II. Our results do not represent, in this instance, the point at which the rapidity of learning begins to decrease, for we did not care to subject our animals to injurious stimulation. We therefore present this conclusion tentatively, subject to correction in the light of future research. Of its correctness we feel confident because of the results which the other sets of experiments gave. The irregularity of curve II, in that it rises slightly for the strength 375 , is due, doubtless, to the small numbers of animals used in the experiments. Had we trained ten mice with each strength of stimulus instead of four the curve probably would have fallen regularly.

4. When the boxes differ only slightly in brightness and discrimination is extremely difficult the rapidity of learning at first rapidly increases as the strength of the stimulus is increased from the threshold, but, beyond an intensity of stimulation which is soon reached, it begins to decrease. Both weak stimuli and strong stimuli result in slow habit-formation. A stimulus whose strength is nearer to the threshold than to the point of harmful stimulation is most favorable to the acquisition of a habit. Curve III verifies these statements. It shows that when discrimination was extremely difficult a stimulus of 195 units was more favorable than the weaker or the stronger stimuli which were used in this set of experiments.

5. As the difficultness of discrimination is increased the strength of that stimulus which is most favorable to habit-formation approaches the threshold. Curve II, curve I, curve III is the order of increasing difficultness of discrimination for our results, for it will be remembered that the experiments of set III were given under difficult conditions of discrimination; those of set I under medium conditions; and those of set II under easy conditions. As thus arranged the most favorable stimuli, so far as we may judge from our results, are 420,300, and 195 . This leads us to infer that an easily acquired habit, that is one which does not 
482 Fournal of Comparative Neurology and Psychology.

demand difficult sense discriminations or complex associations, may readily be formed under strong stimulation, whereas a difficult habit may be acquired readily only under relatively weak stimulation. That this fact is of great importance to students of animal behavior and animal psychology is obvious.

Attention should be called to the fact that since only three strengths of stimulus were used for the experiments of set $\mathrm{I}$, it is possible that the most favorable strength of stimulation was not discovered. We freely admit this possibility, and we furthermore wish to emphasize the fact that our fifth conclusion is weakened slightly by this uncertainty. But it is only fair to add that previous experience with many conditions of discrimination and of stimulation, in connection with which more than two hundred dancers were trained, together with the results of comparison of this set of experiments with the other two sets, convinces us that the dancers would not be likely to learn much more rapidly under any other condition of stimulation than they did with a strength of $300 \pm 25$ units of stimulation.

Naturally we do not propose to rest the conclusions which have just been formulated upon our study of the mouse alone. We shall now repeat our experiments, in the light of the experience which has been gained, with other animals. 